\title{
Differential modulation of nuclear texture, histone acetylation, and $M D R 1$ gene expression in human drug-sensitive and -resistant OV1 cell lines
}

\author{
SONIA YATOUJI ${ }^{1-3}$, VICTORIA EL-KHOURY ${ }^{1}$, CHANTAL TRENTESAUX ${ }^{2}$, AURELIE TRUSSARDI-REGNIER ${ }^{1}$, \\ RYM BENABID $^{1}$, FRANCK BONTEMS ${ }^{1}$ and JEAN DUFER ${ }^{1}$ \\ ${ }^{1}$ Unité MéDIAN, URCA-CNRS UMR 6142, ${ }^{2}$ Laboratoire d'Onco-Pharmacologie, JE 2428, IFR 53, \\ UFR de Pharmacie, 1 rue du Maréchal Juin, 51096 Reims, France; ${ }^{3}$ Laboratoire de Biochimie, \\ Faculté de Médecine, Université du Centre, Monastir, Tunisia
}

Received October 27, 2006; Accepted December 21, 2006

\begin{abstract}
Image cytometric study of pathological specimens or cell lines has suggested that epigenetic mechanisms are likely to play a major role in determining chromatin patterns evaluable through nuclear texture analysis. We previously reported that nuclear textural changes observed in the OV1VCR etoposide-resistant ovarian carcinoma cell line were associated with an increased acetylated histone H4 level. In this study we analyzed the effects of treatments with the HDAC inhibitor trichostatin A (TSA) or with nickel subsulfide on histone $\mathrm{H} 4$ acetylation, nuclear texture, and MDRl gene expression in drug-sensitive IGROV1 and drug-resistant OV1VCR cell lines. In IGROV1 cells, TSA induced an increase in acetylated $\mathrm{H} 4$ level associated with a chromatin textural decondensation and an increase in MDRl gene expression. In OV1-VCR cells, a similar increase in $\mathrm{H} 4$ acetylation was observed, but nuclear texture or $M D R 1$ gene expression remained unchanged. ChIP analysis revealed that MDRI gene expression remained stable in TSA-treated OV1-VCR cells despite a localized increase in $\mathrm{H} 4$ acetylation at the promoter level. Analysis of the methylation status of MDRI promoter showed an increase in DNA methylation at 3 specific sites in OV1-VCR cells, that could participate to TSA low responsiveness in these cells. Treatment with nickel subsulfide induced a decrease in $\mathrm{H} 4$ acetylation without any effect on nuclear texture characteristics in both cell lines. In OV1-VCR cells, nickel subsulfide induced a significant down-regulation of the MDRl gene expression. These results indicate that
\end{abstract}

Correspondence to: Professor Jean Dufer, Unité MéDIAN, URCACNRS UMR 6142, UFR de Pharmacie, 1 rue du Maréchal Juin, F-51096 Reims cedex, France

E-mail: jean.dufer@univ-reims.fr

Key words: drug resistance, trichostatin A, nickel, nuclear texture, histone acetylation, $m d r l$ modulation of histone $\mathrm{H} 4$ acetylation level can be associated with up- or down-regulation of the MDRl gene in OV1 cells. However, this modulation does not always result in chromatin pattern alterations and these data emphasize the complexity of chromatin texture regulation in tumor cells.

\section{Introduction}

Texture analysis of chromatin by image cytometry is an approach that may be used in the development and refinement of diagnoses as well as in the prognosis and the follow-up of cancer (1). This texture, which accounts for the condensation and the distribution of chromatin within the whole nucleus, has provided useful information in the diagnoses and prognoses of various tumor types (2), including ovarian carcinomas (3-5). Concerning therapeutic implications, we and others showed previously significant texture alterations in drug-resistant cell lines $(6,7)$. Particularly, cells overexpressing the efflux pump P-gp encoded by the MDRl ( $A B C B 1)$ gene displayed specific chromatin higher order organization changes (chromatin decondensation, modified organization of chromatin clumps, increased chromatin accessibility) $(6,8)$. This higher order organization is regulated by epigenetic mechanisms as histone acetylation modulation, that could therefore influence nuclear texture measurements $(9,10)$. Previous studies indicated that a treatment with the histone deacetylase inhibitor TSA led to an increase in histone acetylation level that could be partly correlated to some textural changes in the chromatin of small cell lung carcinoma (SCLC) tumor cells (11). However, the consequences on drug-resistance of these cells appear relatively complex and the effect of histone deacetylation was not evaluated. Water-insoluble nickel compounds (nickel sulfide $\mathrm{Ni}_{3} \mathrm{~S}_{6}$ and subsulfide $\mathrm{Ni}_{3} \mathrm{~S}_{2}$ ) have been found to induce gene silencing through the induction of histone $\mathrm{H} 4$ hypoacetylation, together with histone H3K9 dimethylation, DNA methylation, and chromatin condensation (12-16). Further studies showed that nickel inhibits the $\mathrm{H} 4$ acetylation through binding with the N-terminal histidine-18, close to the lysine residues required for acetylation $(12,17)$.

The purpose of this study was to evaluate whether modulation of histone acetylation level by TSA or nickel could 
influence nuclear texture phenotype and $M D R 1$ gene expression in ovarian carcinoma cells.

\section{Materials and methods}

Chemicals. The histone deacetylase inhibitor (HDAC) trichostatin A was purchased from Sigma Aldrich (St. QuentinFallavier, France) and dissolved at a concentration of $1 \mathrm{mg} / \mathrm{ml}$ in DMSO. This stock solution was kept at $-20^{\circ} \mathrm{C}$ and dilution was performed in DMSO to be added at the appropriate concentration to cell cultures. Nickel subsulfide $\left(\mathrm{Ni}_{3} \mathrm{~S}_{2}\right)$ was obtained from Particle Technology Labs (Downers Grove, IL), courtesy of Dr A. Oller (Nipera, Durham, NC). All other chemicals were obtained from standard sources.

Cells. The human ovarian adenocarcinoma cell line IGROV1 and its multidrug-resistant variant OV1/VCR selected with vincristine were provided by Dr J. Bénard (Institut Gustave Roussy, Villejuif, France). The two cell lines were grown as previously reported (8). The OV1/VCR cell index of resistance against vincristine is around 700 (18). Cells were allowed to attach for at least $24 \mathrm{~h}$ before treatments. The control cultures were treated with vehicle alone.

Image cytometry. Cells were cultured in lab-tek chambered $\left(4 \mathrm{~cm}^{2}\right)$ slides (Nunc, Naperville, USA). Cells were air-dried, fixed, and stained by the Feulgen method as previously described (6). Image cytometry was performed with an image analysis system (SAMBA 2005, Samba Technologies, Meylan, France) as reported (8). At least 200 cells were analyzed on each microscopic slide and 3 separate experiments were performed. Percentages of cells in the different cell cycle phases were computed on the basis of their DNA-integrated optical density and $\mathrm{G}_{0}-\mathrm{G}_{1}$ nuclei were extracted as reported (6). Nine textural features were calculated on these $G_{0} / G_{1}$ nuclear images after reduction to 16 gray levels by linear rescaling. Four features were calculated on the gray-levels co-occurrence matrix: local mean of gray levels (LM), energy (E), entropy (ENT), and inertia (I). Five parameters were calculated on the run-length matrix: short run-length emphasis (SRE), long run-length emphasis (LRE), gray level distribution (GLD), run-length distribution (RLD), and runlength percentage (RPC) $(19,20)$.

The distribution, means, and SD of the nuclear parameters were calculated for each cell population. Differences between groups were analyzed by discriminant analysis completed by a canonical analysis. This feature-reduction technique derives canonical variables (CVs), which are linear combinations of the independent quantitative variables. Usually, the first $\mathrm{CV}$ is the most important, in that it shows the highest variation among the groups. Significance of the differences between parameters and CV values was estimated by Student's t-test after Bonferonni correction for multiple groups and variables.

RT/PCR analysis. Total cellular RNA was prepared using the guanidine isothiocyanate/acid/phenol method (Tri Reagent: Sigma Chemical Co., St. Louis, MO, USA). MDR1 and $\beta 2-$ microglobulin $(\beta 2 m)$ transcripts were analyzed by semiquantitative reverse-transcription polymerase-chain-reaction
(RT/PCR) as reported previously (8). The $\beta 2 m$ gene was used as an internal control.

Immunoblotting of histones. Histones were isolated and analyzed as previously described (8). Briefly, equal amounts of acid extracted histones were analyzed on an SDS-18\% polyacrylamide gel and transferred onto Immobilon-P membranes (Millipore, Saint Quentin-en-Yvelines, France). Membranes were probed overnight at $4{ }^{\circ} \mathrm{C}$ with specific primary antibody (Upstate Biotechnology, Lake Placid, NY, USA) against acetylated histone H4 (diluted 1:2000). Proteins were visualized using a peroxidase-conjugated anti-rabbit secondary antibody (Amersham Life Science, UK) at 1:10000, and the ECL detection kit (Amersham).

Chromatin immunoprecipitation (ChIP) assay. Chromatin immunoprecipitation was performed using a ChIP assay kit (Upstate Biotechnology) according to the manufacturer's protocol. In brief, IGROV1 and OV1/VCR cells were grown to $80 \%$ confluency in $10-\mathrm{cm}$ dishes $\left(1.5 \times 10^{5}\right.$ cells $\left./ \mathrm{ml}\right)$ and treated or not with TSA $(100 \mathrm{ng} / \mathrm{ml})$. After 12-h incubation, chromatin was cross linked with $1 \%$ formaldehyde. Cells were washed twice with PBS containing protease inhibitor cocktail (Roche Molecular Biochemicals, Basel, Switzerland), scraped, and resuspended in SDS-lysis buffer. Samples were sonicated, sheared chromatin was centrifuged for $10 \mathrm{~min}$ at $13,000 \mathrm{rpm}$ at $4^{\circ} \mathrm{C}$, and supernatants were diluted 10 -fold in ChIP dilution buffer containing protease inhibitors as above. As input controls during the PCR, $3 \%$ of each diluted supernatant was retained at this step. Sheared chromatin was precleared with $80 \mu 1$ of Salmon Sperm DNA/Protein A agarose for $30 \mathrm{~min}$ at $4^{\circ} \mathrm{C}$ with agitation. Beads were pelleted and supernatants were immunoprecipitated overnight with antiacetylated histone H4 antibody (Upstate Biotechnology). Immunoprecipitated DNA (both immunoprecipitation samples and inputs) was recovered by phenol/chlorophorm extraction and ethanol precipitation, and analyzed by PCR. GAPDH was used as control. Primer sequences used were as follows: MDR1 (GenBank accession no. L07624) promoter: 5'- CATC CTCAGACTATGCAGTA-3' (forward), 5'-GCTAACTCAC ATCAGAGCTT-3' (reverse); GAPDH proximal promoter: 5'-GTGCGTGCCCAGTTGAACCA-3' (forward), 5'-CGGCT GACTGTCGAACAGGA-3' (reverse). After an initial incubation step for $5 \mathrm{~min}$ at $95^{\circ} \mathrm{C}, 30 \mathrm{PCR}$ cycles were performed. The cycling conditions consisted of denaturation at $95^{\circ} \mathrm{C}$ for $50 \mathrm{sec}$, annealing for $50 \mathrm{sec}$ at $58^{\circ} \mathrm{C}$ for $M D R l$ promoter or $60^{\circ} \mathrm{C}$ for $G A P D H$ promoter and $72^{\circ} \mathrm{C}$ for $50 \mathrm{sec}$, and one cycle at $72^{\circ} \mathrm{C}$ for $10 \mathrm{~min}$. PCR aliquots $(10 \mu \mathrm{l})$ were subjected to electrophoresis on $2 \%$ agarose gel stained with ethidium bromide.

Methylation-specific PCR. Genomic DNA was isolated using a NucleoSpin Tissue kit (Macherey-Nagel, France), denaturated in $0.3 \mathrm{~mol} / 1 \mathrm{NaOH}$, and incubated with $0.5 \mathrm{mM}$ hydroquinone and $3.1 \mathrm{~mol} / 1$ sodium bisulfite $(\mathrm{pH} 5.0)$ for $16 \mathrm{~h}$ at $50^{\circ} \mathrm{C}$. DNA was precipitated with ammonium acetate and ethanol, washed with $70 \%$ ethanol, and resuspended in distilled water. The bisulfite-modified DNA samples were amplified by primers specific for both methylated and unmethylated sequences of the $-50 \mathrm{GC}$ and $-110 \mathrm{GC}$ boxes of the MDRl promoter. The 
primer sequences (Sigma-Proligo, Paris, France) were as follows: -50GC box, methylated 5'-GTTGGGTAGGAATAG CGTC-3' (forward) and 5'-CCTCAAAAAACCCTTCTCC-3' (reverse); unmethylated 5'-TAGGAATAGTGTTGGGGTG-3' (forward) and 5'-CCTCAAAAAACCCTTCTCC-3' (reverse); -110GC box, methylated 5'-TATTTAGTTAATTCGGGTCG3' (forward) and 5'-CCTCAAAAAACCCTTCTCC-3' (reverse); unmethylated 5'-TTTAGTTAATTTGGGTTGGG-3' (forward) and 5'-CCTCAAAAAACCCTTCTCC-3' (reverse). DNA amounts were controlled using a primer set designed to amplify both methylated and unmethylated sequences of the region including -50GC and -110GC boxes: 5'-GGTGATAT AGAATTGGAGAGG-3' (forward) and 5'-CCTCAAAAAA CCCTTCTCC-3' (reverse). PCR products were analyzed in $2 \%$ agarose gel stained with ethidium bromide.

Combined bisulfite restriction analysis (COBRA). Bisulfite modified genomic DNA was amplified by PCR. Primers designed for the bisulfite modified sequence of the Inr region $(-20$ to +172$)$ of the $M D R 1$ promoter were: 5'-GTTATAGGA AGTTTGAGTTT-3' (forward) and 5'- AAAAACTATCCCA TAATAAC-3' (reverse) (Sigma-Proligo). Purified PCR products (192 bp) were digested with restriction enzyme TaqI (Invitrogen, Cergy, France), which recognizes the TCGA sequence unique to the methylated and bisulfite-converted DNA of the methylated alleles of the Inr site. DNA samples were precipitated and electrophoresed in $2.5 \%$ agarose gel stained with ethidium bromide. The intensity of methylated alleles was calculated by densitometry using a Typhoon 9210 scanner and Image Quant analysis software (Amersham Biosciences).

\section{Results}

In order to investigate the relationships between nuclear texture, histone acetylation, and MDR1 gene expression, drug-sensitive IGROV1 and drug-resistant OV1-VCR cells were exposed or not to the HDAC inhibitor TSA $(100 \mathrm{ng} / \mathrm{ml})$ and to nickel subsulfide $\left(1 \mu \mathrm{g} / \mathrm{cm}^{2}\right)$ for up to $24 \mathrm{~h}$. These concentrations were reported as optimal for induction of histone modifications without significant toxicity.

Nuclear texture analysis was performed and the values of the 9 textural features were estimated in $\mathrm{G}_{0} / \mathrm{G}_{1}$ cells. The data obtained were submitted to a discriminant analysis combined to a canonical analysis. The values of the first canonical variable (CV1) which explains $53 \%$ of the variance between the groups appear in Fig. 1. As previously reported, OV1VCR cells displayed very significantly different nuclear texture characteristics, as compared to IGROV1 drugsensitive cells (8). In the same way, when IGROV1 cells were treated with TSA, their chromatin texture showed significant alterations. The specific weight of the different computed parameters in the CV1 calculation is shown in Table I. The parameters have been ranked by weight absolute values and a minus sign implies a negative contribution to CV1 computation for the corresponding parameter. Analysis of Fig. 1 and Table I shows that TSA-treated IGROV1 cells displayed a chromatin decondensation (decrease of ENT, RPC, and I), with a less compact chromatin distribution (increase in E), and the appearance of a more homogeneous

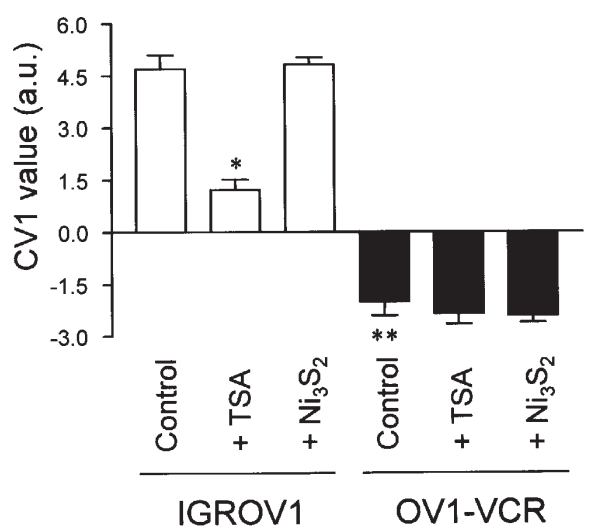

Figure 1. Analysis of nuclear texture in human ovarian adenocarcinoma IGROV1 and OV1/VCR cell lines treated or not for $24 \mathrm{~h}$ with TSA $(100 \mathrm{ng} / \mathrm{ml})$ or $\mathrm{Ni}_{3} \mathrm{~S}_{2}\left(1 \mu \mathrm{g} / \mathrm{cm}^{2}\right)$. First canonical variable (CV1) values were expressed in arbitrary units (a.u.). ${ }^{*} \mathrm{p}<0.05 ;{ }^{* *} \mathrm{p}<0.01$ as compared to IGROV1 control values (Student's t-test after Bonferroni correction).

Table I. Specific weight values of textural parameters in the computation of the first canonical variable.

\begin{tabular}{lc}
\hline Parameter $^{\mathrm{a}}$ & $\begin{array}{c}\text { Specific weight in CV1 } \\
\text { computation (a.u.) }\end{array}$ \\
\hline ENT & 10.85 \\
SRE & -7.12 \\
RPC & 6.96 \\
I & 6.02 \\
GLD & -5.85 \\
E & -4.17 \\
LM & 2.80 \\
LRE & -2.43 \\
RLD & -1.76 \\
\hline
\end{tabular}

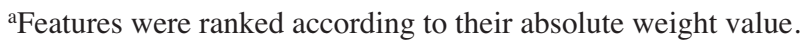

texture (increases in SRE, GLD, and LRE). On the contrary, IGROV1 cells treated with $\mathrm{Ni}_{3} \mathrm{~S}_{2}$ did not display chromatin changes as measured by image cytometry. Similarly, OV1VCR cells treated with TSA or $\mathrm{Ni}_{3} \mathrm{~S}_{2}$ presented unaltered nuclear texture characteristics as compared to control untreated cells.

In order to investigate if the level of histone $\mathrm{H} 4$ acetylation could play some role in these chromatin structural changes observed in IGROV1 drug-sensitive cells, this expression was analyzed by immunoblotting using anti-acetylated $\mathrm{H} 4$ antibody. As previously reported (8), OV1-VCR cells displayed a significant increased level of acetylated histone H4. TSA treatment for $24 \mathrm{~h}$ induced a marked increase in $\mathrm{H} 4$ acetylation both in IGROV1 and OV1-VCR cells. On the contrary, $\mathrm{Ni}_{3} \mathrm{~S}_{2}$ treatment decreased this $\mathrm{H} 4$ acetylation level in the two sublines (Fig. 2).

As histone post translational modifications, and particularly histone acetylation, have been shown to play an important 


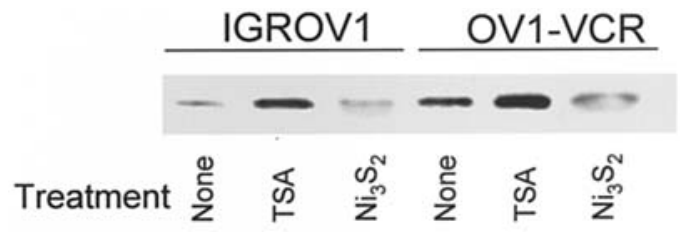

Figure 2. TSA or nickel subsulfide effects on histone $\mathrm{H} 4$ acetylation level. Nuclear extracted histones from IGROV1 and OV1/VCR cells, both treated for $24 \mathrm{~h}$ or not with TSA or $\mathrm{Ni}_{3} \mathrm{~S}_{2}$ were resolved by SDS-PAGE, transferred to nitrocellulose membranes, and probed with specific anti-acetylated histone $\mathrm{H} 4$ monoclonal antibody. A representative experiment from a series of three is shown.

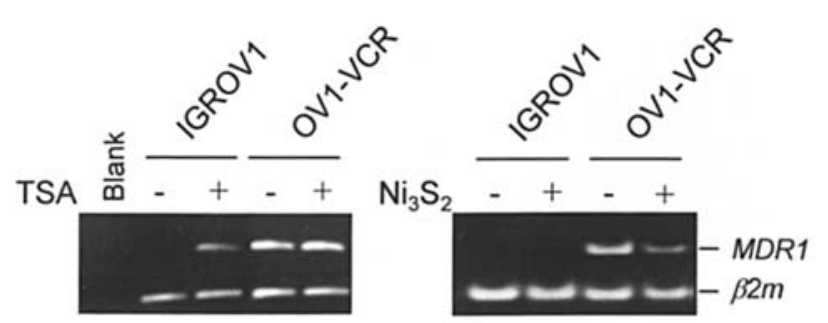

Figure 3. Semi-quantitative RT-PCR assay for the MDR1 gene in IGROV1 cell and OV1/VCR cells. Cells were treated or not for $24 \mathrm{~h}$ with TSA $(100 \mathrm{ng} / \mathrm{ml}$, left panel) or $\mathrm{Ni}_{3} \mathrm{~S}_{2}\left(1 \mu \mathrm{g} / \mathrm{cm}^{2}\right.$, right panel). $\beta 2$-microglobulin $(\beta 2 m)$ was used as internal control. A representative experiment from a series of three is shown.

role in MDRl gene regulation, the expression of this gene was explored by RT-PCR in IGROV1 and OV1-VCR cells treated or not with TSA or $\mathrm{Ni}_{3} \mathrm{~S}_{2}$ for $24 \mathrm{~h}$. The results of these analyses appear in Fig. 3. TSA treatment induced a significant increase of MDRI gene expression in IGROV1 cells (where basal expression could not be recorded), whereas gene expression was unaffected in OV1-VCR cells. This TSAinduced increase in IGROV1 cells appeared early after 8-h treatment and displayed a plateau until $24 \mathrm{~h}$ (data not shown). On the contrary, MDRl gene expression did not vary and remained completely silenced in IGROV1 cells treated with $\mathrm{Ni}_{3} \mathrm{~S}_{2}$. However, this treatment with $\mathrm{Ni}_{3} \mathrm{~S}_{2}$ down-regulated MDR1 gene expression in the drug-resistant OV1-VCR cells.

To further analyze the differences in MDR1 gene response to TSA despite the similar global nuclear $\mathrm{H} 4$ acetylation level increases observed in IGROV1 and OV1-VCR cells, we performed ChIP assays to determine $\mathrm{H} 4$ acetylation changes within the MDR1 promoter. After 12-h treatment with TSA, $\mathrm{H} 4$ acetylation increased at the MDRI promoter level, both in drug-sensitive and -resistant cells (2- and 3.5-fold increases, respectively). On the contrary, the $\mathrm{H} 4$ acetylation levels at the promoter of the HDAC insensitive GAPDH gene remained unchanged (Fig. 4).

As it has been reported that TSA effect on MDRI gene expression could be related to the methylation status of the gene promoter, we analyzed, by methylation-specific PCR, the methylation status of 2 specific GC boxes (-50 and -110GC boxes) in the MDRI gene promoter. The results obtained in IGROV1 and OV1-VCR cells were compared to those from hypermethylated (MCF7) or hypomethylated (peripheral blood mononuclear cells, PBMC) controls. -50 and $-110 \mathrm{GC}$

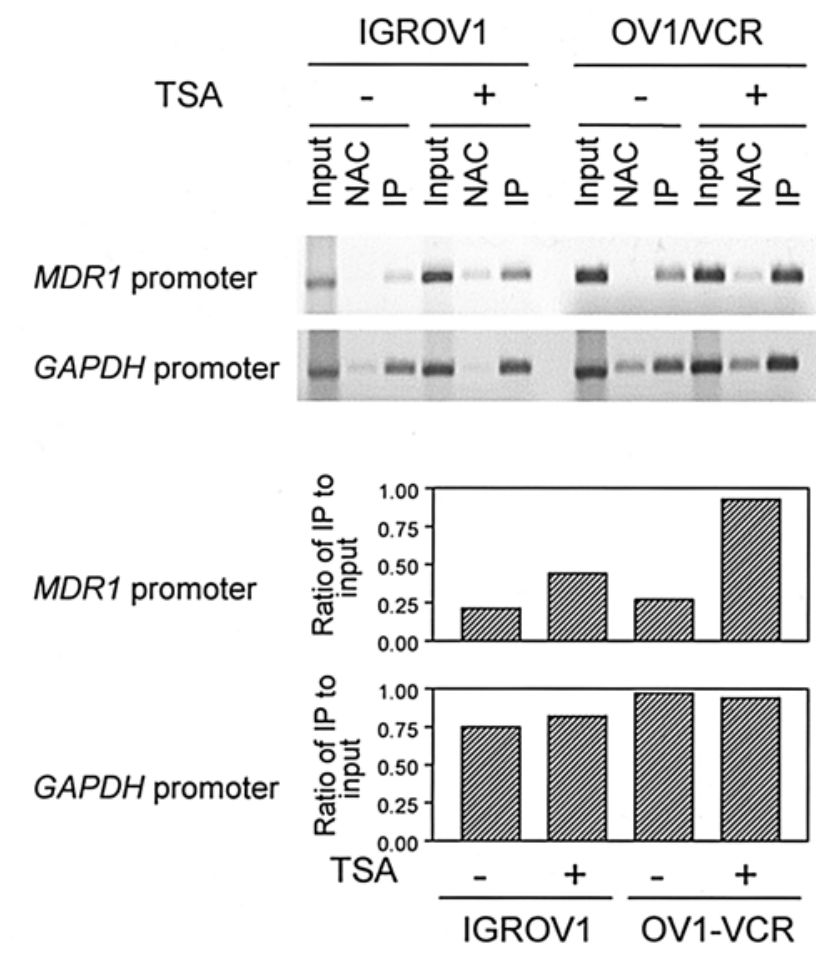

Figure 4. TSA effect on the accumulation of acetylated histone $\mathrm{H} 4$ in chromatin associated with $M D R 1$ and $G A P D H$ promoter regions in IGROV1 and OV1/VCR cell lines treated with or without TSA $(100 \mathrm{ng} / \mathrm{ml})$ for $12 \mathrm{~h}$. Chromatin immunoprecipitation (ChIP assay) was performed using antiacetylated histone $\mathrm{H} 4$ antibody. The data represents agarose gel electrophoretic separation of amplicons obtained after PCR (a representative experiment from a series of three is shown). Input DNA served as positive internal control for sample integrity.

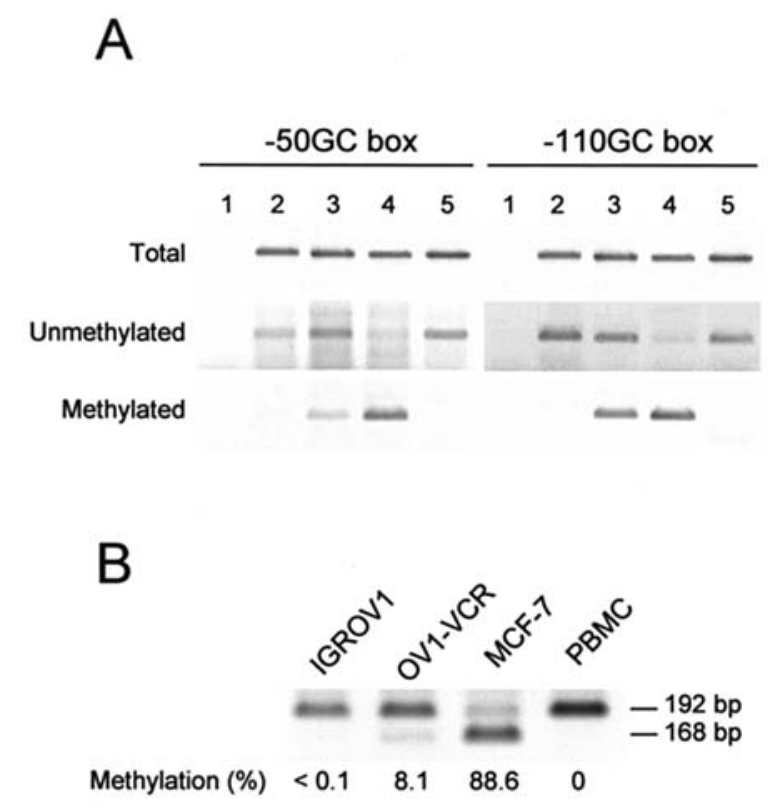

Figure 5. Methylation status of the $M D R 1$ promoter. A, methylation-specific PCR of MDR1 -50GC box and -110GC box. Primer sets are designed to amplify methylated and unmethylated alleles. A primer encompassing both alleles' whole GC region (total) was used as loading control. Lanes 1, blank control; lanes 2, IGROV1 cells; lanes 3, OV1-VCR cells; lanes 4, MCF7 cells; lanes 5, PBMC. A representative experiment from a series of three is shown. $\mathrm{B}$, COBRA analysis of the Inr sequence. Figures represent the methylation percentages observed in the different samples (mean of 2 separate independent experiments). MCF7 cells and PBMC were used as positive controls for methylated and unmethylated sites, respectively. 
boxes appear hypomethylated in IGROV1 cells (Fig. 5A, lanes 2). On the contrary, a higher level of methylation of these 2 GC boxes was observed in OV1-VCR cells (Fig. 5A, lanes 3), with a more marked increase at the $-110 \mathrm{GC}$ box level. This was confirmed by the COBRA analysis of the Inr sequence where the methylation level in OV1-VCR reached $8.5 \%$ vs $<0.1 \%$ only in IGROV1 cells (Fig. $5 \mathrm{~B}$ ).

\section{Discussion}

Nuclear texture is a reflection of the overall structure of the nuclear chromatin $(1,8)$. Studies of the differences in nuclear texture features have proved to be useful for the development of treatment protocols or to be effective as markers for cancer screening $(1,2)$. However, the mechanisms that support modifications in nuclear texture remain to be determined. Changes in chromatin appearance may reflect changes in the activation patterns of genes and epigenetic mechanisms may then play a pivotal role in texture phenotype definition. We showed previously that drug-resistant OV1-VCR cells displayed specific chromatin texture characteristics associated with an increase in histone $\mathrm{H} 4$ acetylation level, as compared to their drug-sensitive IGROV1 counterparts (8). This suggests that histone acetylation could be implicated in texture changes and histone hyperacetylation by HDAC inhibition was accompanied by chromatin textural alterations in SCLC tumor cells (11). In this work, we compared the effects of an up- or down-regulation of histone $\mathrm{H} 4$ acetylation level on nuclear texture and $M D R 1$ gene expression in drug-sensitive IGROV1 and Pg-P positive drug-resistant OV1-VCR cells. Increase in $\mathrm{H} 4$ acetylation was induced by the HDAC inhibitor TSA and decrease in $\mathrm{H} 4$ acetylation by treatment of cells with waterinsoluble $\mathrm{Ni}_{3} \mathrm{~S}_{2}$ particles.

IGROV1 cells treated with TSA displayed an increase in acetylated histone $\mathrm{H} 4$ level and a chromatin decondensation. Previous reports indicated that TSA could induce interphasic chromatin decondensation through its HDAC inhibitory activity $(21,22)$. This increase in histone acetylation seemed not to result in a new distribution of chromosome territories, but rather to modulate their respective condensation levels (23). HDAC inhibition by TSA would therefore not mainly alter global spatial arrangement of euchromatin and heterochromatin, but rather would increase their compartmentation. The changes we observed in chromatin texture were in accord with these data, as TSA-treated IGROV1 cells displayed simultaneous increases in LRE (appearance of a finer and homogeneous chromatin texture) and SRE (increase in density of chromatin clumps), suggesting a more distinct delimitation of the different chromatin forms. This phenomenon was already observed in OV1-VCR untreated drug-resistant cells which present an increased spontaneous $\mathrm{H} 4$ acetylation level (8).

In these drug-resistant cells, TSA treatment also induced $\mathrm{H} 4$ acetylation increase, but unexpectedly did not result in any nuclear texture change. This suggests that $\mathrm{H} 4$ acetylation is only one epigenetic phenomenon that could play a role in nuclear texture changes, and other histone post-translational modifications could be implicated as well. Preliminary data on SCLC cells indicate that dimethylation of H3K9, which correlated often with silenced chromatin, was probably not linked to texture (El Khoury, unpublished data). Conversely,
$\mathrm{H} 1$ and $\mathrm{H} 3$ phosphorylation has been associated with chromatin condensation during the mitotic process $(24,25)$ or after TSA treatment in HT-29 colon carcinoma cell line (26). Moreover, the transcriptional co-activator p300 with HAT activity increases histone acetylation and modulates nuclear texture through lamin A and $\mathrm{C}$ up-regulation, suggesting that these matrix proteins could also mediate nuclear phenotype changes (27). Interestingly, chromatin texture alterations observed in drug-resistant cells were also associated with nuclear matrix reorganization in CEM cells (28).

A similar unresponsiveness in TSA-treated OV1-VCR cells was observed at the level of MDRl gene expression. Significant progress has been reported in the definition of the mechanisms that regulate $M D R 1$ gene expression in tumor cells (29-31). Among these, epigenetic phenomena (DNA methylation, histone acetylation) play a major role in this control $(32,33)$. TSA treatment provoked MDR1 gene upregulation in IGROV1 cells. This increase in gene expression was associated with a localized $\mathrm{H} 4$ acetylation increase at the gene promoter region. A similar global and local H4 acetylation increase was observed in the nucleus and at the MDR1 promoter region of OV1-VCR cells, but did not result in gene up-regulation. It has been proposed that TSA could induce $M D R 1$ gene up-regulation when the gene promoter is hypomethylated, either spontaneously or through pharmacological modulation (34). Similarly, a synergy between DNA methylation and histone deacetylation was observed where hypermethylated genes cannot be reactivated by TSA (35). $M D R I$ gene promoter GC boxes and Inr sequence appeared to be hypomethylated in IGROV1 cells and this supports the fact that TSA alone was able to up-regulate gene expression in these drug-sensitive cells. OV1-VCR cells, which appeared less sensitive to TSA effects, displayed at the MDR1 promoter level an increase in the methylation of the -50GC and -110GC boxes, or of the Inr sequence site. Then, this methylation increase was able to participate in the impairment of TSAinduced gene up-regulation. However, a wider sequence analysis of the promoter is required to confirm the hypermethylation of the promoter $\mathrm{CpG}$ sites.

Nickel salts, and particularly water-insoluble $\mathrm{Ni}_{3} \mathrm{~S}_{2}$, have been shown to affect chromatin structure and to alter the expression of a surprisingly large number of genes, e.g. thrombospondin, telomer marker, or senescence genes (36). Inhibition of gene expression has been functionally associated with nickel-mediated deacetylation of histones $\mathrm{H} 3$ and $\mathrm{H} 4$ $(12,16,37)$. Treatment of IGROV1 and OV1-VCR cells with $\mathrm{Ni}_{3} \mathrm{~S}_{2}$ resulted in a decrease in histone $\mathrm{H} 4$ acetylation level in both cell lines as evaluated by Western blotting. Furthermore, this hypoacetylation was associated with a down-regulation of the MDR1 gene expression in the drug-resistant OV1-VCR cells. This data seemed to confirm the sensitivity of this gene to the epigenetic regulatory machinery (33), although nickelinduced local histone hypoacetylation has to be confirmed at the promoter level. However, treatment of cells with $\mathrm{Ni}_{3} \mathrm{~S}_{2}$ did not result in significant textural changes, both in IGROV1 and OV1-VCR cells. This data suggests that histone H4 hypoacetylation did not correlate with global chromatin modifications. These results correlate well with a previous report indicating that, during apoptosis pathway induced by sodium butyrate in thymocytes, the histone $\mathrm{H} 4$ hypoacetylation 
was not responsible for the chromatin condensation observed (38). Furthermore, recent data indicated that nickel ions inhibit gene expression also through an increase in histone H3K9 dimethylation (13), a marker that seems independent of nuclear texture changes in SCLC cells (El-Khoury, unpublished data).

Reports on image cytometric study of pathological specimens or cell lines suggested that epigenetic mechanisms such as histone acetylation were likely to play a major role in determining chromatin pattern $(8,39)$. The results presented here confirm that histone acetylation changes in drug-sensitive and -resistant OV1 cells can occur simultaneously with $M D R 1$ gene modulation and can be related to nuclear texture changes in some specific situations. However, regulation of chromatin texture alterations associated with drug-resistance appears to be a highly complex phenomenon. Further study is needed to define genetic and epigenetic mechanisms other than histone acetylation, together with nuclear matrix changes, that are likely to be implicated in this regulation.

\section{Acknowledgements}

This study was supported by grants from ARERS and from the Comités départementaux des Ardennes, de la Marne et de l'Aube de la Ligue Française contre le Cancer. S.Y. and V.E-K. were recipients of a fellowship from the Comité Départemental de la Haute Marne de la Ligue contre le Cancer and from ARERS, respectively. We wish to thank Adriana Oller (Nipera) for nickel subsulfide, and J. Benard for OV1 cell lines.

\section{References}

1. Doudkine A, Macaulay C, Poulin N and Palcic B: Nuclear texture measurements in image cytometry. Pathologica 87: 286-299, 1995.

2. Millot C and Dufer J: Clinical applications of image cytometry to human tumour analysis. Histol Histopathol 15: 1185-1200, 2000.

3. Deligdisch L, Miranda C, Barba J and Gil J: Ovarian dysplasia: nuclear texture analysis. Cancer 72: 3253-3257, 1993.

4. Geisler JP, Geisler HE, Miller GA, Wiemann MC, Zhou Z and Crabtree W: Markov optical texture parameters as prognostic indicators in ovarian carcinoma. Int J Gynecol Cancer 9: 317-321, 1999.

5. Nielsen B, Albregtsen F, Kildal W and Danielsen HE: Prognostic classification of early ovarian cancer based on very low dimensionality adaptive texture feature vectors from cell nuclei from monolayers and histological sections. Anal Cell Pathol 23: 75-88, 2001.

6. Dufer J, Millot-Broglio C, Oum'Hamed Z, Liautaud-Roger F, Joly P, Desplaces A and Jardillier JC: Nuclear DNA content and chromatin texture in multidrug-resistant human leukemic cell lines. Int J Cancer 60: 108-114, 1995.

7. Pauwels $\mathrm{O}$ and Kiss R: Computerized morphonuclear analyses of Feulgen-stained nuclei from 11 chemosensitive and from 11 chemoresistant neoplastic cell lines. Anal Cell Pathol 7: 235-250, 1994.

8. Yatouji S, Trussardi-Regnier A, Trentesaux C, Liautaud-Roger F and Dufer $\mathrm{J}$ : Nuclear texture and chromatin structure in OV1/VCR human multidrug-resistant cell line. Int J Oncol 23: 1225-1230, 2003

9. Berger SL: Histone modifications in transcriptional regulation. Curr Opin Genet Dev 12: 142-148, 2002.

10. Grunstein M: Histone acetylation in chromatin structure and transcription. Nature 389: 349-352, 1997.

11. El-Khoury V, Gomez D, Liautaud-Roger F, Trussardi-Regnier A and Dufer J: Effects of the histone deacetylase inhibitor trichostatin A on nuclear texture and c-jun gene expression in drugsensitive and drug-resistant human H69 lung carcinoma cells. Cytometry A 62: 109-117, 2004.
12. Broday L, Peng W, Kuo MH, Salnikow K, Zoroddu M and Costa M: Nickel compounds are novel inhibitors of histone H4 acetylation. Cancer Res 60: 238-241, 2000

13. Chen H, Ke Q, Kluz T, Yan Y and Costa M: Nickel ions increase histone $\mathrm{H} 3$ lysine 9 dimethylation and induce transgene silencing. Mol Cell Biol 26: 3728-3737, 2006.

14. Golebiowski F and Kasprzak KS: Inhibition of core histones acetylation by carcinogenic nickel(II). Mol Cell Biochem 279: 133-139, 2005.

15. Kang J, Zhang D, Chen J, Lin C and Liu Q: Involvement of histone hypoacetylation in $\mathrm{Ni}^{2+}$-induced bcl-2 down-regulation and human hepatoma cell apoptosis. J Biol Inorg Chem 9: 713-723, 2004.

16. Lee YW, Klein CB, Kargacin B, Salnikow K, Kitahara J, Dowjat K, Zhitkovich A, Christie NT and Costa M: Carcinogenic nickel silences gene expression by chromatin condensation and DNA methylation: a new model for epigenetic carcinogens. Mol Cell Biol 15: 2547-2557, 1995.

17. Zoroddu MA, Kowalik-Jankowska T, Kozlowski H, Molinari H, Salnikow K, Broday L and Costa M: Interaction of Ni(II) and $\mathrm{Cu}(\mathrm{II})$ with a metal binding sequence of histone H4: AKRHRK, a model of the H4 tail. Biochim Biophys Acta 1475: 163-168, 2000.

18. Benard J, Da Silva J, Teyssier JR and Riou G: Over-expression of MDR1 gene with no DNA amplification in a multiple-drugresistant human ovarian carcinoma cell line. Int J Cancer 43: 471-477, 1989.

19. Galloway MM: Texture analysis using gray-level run lengths. Comp Graph Image Proc 4: 172-179, 1975.

20. Haralick RM, Shanmugan K and Dinstein I: Textural features for image classification. IEEE Trans Syst Man Cyber SMC 3: 610-621, 1973.

21. Bartova E, Pachernik J, Harnicarova A, Kovarik A, Kovarikova M, Hofmanova J, Skalnikova M, Kozubek M and Kozubek S: Nuclear levels and patterns of histone H3 modification and HP1 proteins after inhibition of histone deacetylases. J Cell Sci 118: 5035-5046, 2005

22. Toth KF, Knoch TA, Wachsmuth M, Frank-Stohr M, Stohr M, Bacher CP, Muller G and Rippe K: Trichostatin A-induced histone acetylation causes decondensation of interphase chromatin. J Cell Sci 117: 4277-4287, 2004.

23. Gilchrist S, Gilbert N, Perry P and Bickmore WA: Nuclear organization of centromeric domains is not perturbed by inhibition of histone deacetylases. Chromosome Res 12: 505-516, 2004.

24. Khorasanizadeh S: The nucleosome: from genomic organization to genomic regulation. Cell 116: 259-272, 2004.

25. Strahl BD and Allis CD: The language of covalent histone modifications. Nature 403: 41-45, 2000.

26. Biade S, Stobbe CC, Boyd JT and Chapman JD: Chemical agents that promote chromatin compaction radiosensitize tumour cells. Int J Radiat Biol 77: 1033-1042, 2001.

27. Debes JD, Sebo TJ, Heemers HV, Kipp BR, De Haugen AL, Lohse CM and Tindall DJ: p300 modulates nuclear morphology in prostate cancer. Cancer Res 65: 708-712, 2005.

28. Rafki-Beljebbar N, Liautaud-Roger F, Ploton D and Dufer J: Textural analysis of nuclear mitotic apparatus antigen (NuMA) spatial distribution in interphase nuclei from human drugresistant CEM lymphoblasts. Anal Cell Pathol 18: 175-181, 1999.

29. Chen KG, Wang YC, Schaner ME, Francisco B, Duran GE, Juric D, Huff LM, Padilla-Nash H, Ried T, Fojo T and Sikic BI: Genetic and epigenetic modeling of the origins of multidrugresistant cells in a human sarcoma cell line. Cancer Res 65: 9388-9397, 2005.

30. Labialle S, Gayet L, Marthinet E, Rigal D and Baggetto LG: Transcriptional regulators of the human multidrug resistance 1 gene: recent views. Biochem Pharmacol 64: 943-948, 2002.

31. Scotto KW: Transcriptional regulation of ABC drug transporters. Oncogene 22: 7496-7511, 2003.

32. Baker EK and El Osta A: The rise of DNA methylation and the importance of chromatin on multidrug resistance in cancer. Exp Cell Res 290: 177-194, 2003.

33. Baker EK, Johnstone RW, Zalcberg JR and El-Osta A: Epigenetic changes to the MDR1 locus in response to chemotherapeutic drugs. Oncogene 24: 8061-8075, 2005.

34. El-Osta A, Kantharidis P, Zalcberg JR and Wolffe AP: Precipitous release of methyl-CpG binding protein 2 and histone deacetylase 1 from the methylated human multidrug resistance gene (MDR1) on activation. Mol Cell Biol 22: 1844-1857, 2002 . 
35. Cameron EE, Bachman KE, Myohanen S, Herman JG and Baylin SB: Synergy of demethylation and histone deacetylase inhibition in the re-expression of genes silenced in cancer. Nat Genet 21: 103-107, 1999.

36. Beyersmann D: Effects of carcinogenic metals on gene expression. Toxicol Lett 127: 63-68, 2002.

37. Kang J, Zhang Y, Chen J, Chen H, Lin C, Wang Q and Ou Y: Nickel-induced histone hypoacetylation: the role of reactive oxygen species. Toxicol Sci 74: 279-286, 2003.
38. D'Arrigo C, Barboro P, Mormino M, Coradeghini R, Parodi S, Patrone $\mathrm{E}$ and Balbi C: DNA supercoiling in apoptotic chromatin. Biochem Biophys Res Commun 309: 540-546, 2003

39. Montironi R, Thompson D, Scarpelli M, Mazzucchelli R, Peketi P, Hamilton PW, Bostwick DG and Bartels PH: Karyometry detects subvisual differences in chromatin organization state between cribriform and flat high-grade prostatic intraepithelial neoplasia. Mod Pathol 17: 928-937, 2004. 